\title{
Evaluation of Antithrombogenic pHPC on CoCr Substrates for Biomedical Applications
}

\author{
Catrin Bannewitz ${ }^{1, *(1)}$, Tim Lenz-Habijan ${ }^{1}{ }^{(\mathbb{D}}$, Jonathan Lentz ${ }^{2}$, Marcus Peters ${ }^{3}(D)$, Volker Trösken ${ }^{1}$, \\ Sabine Siebert ${ }^{2}$, Sebastian Weber ${ }^{2}$, Werner Theisen ${ }^{2}$, Hans Henkes ${ }^{4}$ and Hermann Monstadt ${ }^{1}$ \\ 1 phenox GmbH, Lise-Meitner-Allee 31, 44801 Bochum, Germany; tim.habijan@rub.de (T.L.-H.); \\ volker.troesken@phenox.info (V.T.); hermann.monstadt@phenox.info (H.M.) \\ 2 Lehrstuhl Werkstofftechnik, Ruhr-Universität Bochum, Universitätsstrasse 150, 44801 Bochum, Germany; \\ lentz@wtech.rub.de (J.L.); siebert@wtech.rub.de (S.S.); weber@wtech.rub.de (S.W.); \\ theisen@wtech.rub.de (W.T.) \\ 3 Department of Molecular Immunology, Ruhr-Universität Bochum, Universitätsstrasse 150, \\ 44801 Bochum, Germany; marcus.peters@rub.de \\ 4 Neuroradiologische Klinik, Klinikum Stuttgart, Kriegsbergstraße 60, 70174 Stuttgart, Germany; \\ hhhenkes@aol.com \\ * Correspondence: catrin.bannewitz@rub.de
}

check for updates

Citation: Bannewitz, C.; Lenz-Habijan, T.; Lentz, J.; Peters, M.; Trösken, V.; Siebert, S.; Weber, S.;

Theisen, W.; Henkes, H.; Monstadt, H. Evaluation of Antithrombogenic pHPC on CoCr Substrates for Biomedical Applications. Coatings 2021, 11, 93. https://doi.org/ 10.3390/coatings11010093

Received: 18 December 2020 Accepted: 13 January 2021 Published: 15 January 2021

Publisher's Note: MDPI stays neutral with regard to jurisdictional clai$\mathrm{ms}$ in published maps and institutional affiliations.

Copyright: (C) 2021 by the authors. Licensee MDPI, Basel, Switzerland. This article is an open access article distributed under the terms and conditions of the Creative Commons Attribution (CC BY) license (https:// creativecommons.org/licenses/by/ $4.0 /)$.

\begin{abstract}
Bare metal endovascular implants pose a significant risk of causing thrombogenic complications. Antithrombogenic surface modifications, such as phenox's "Hydrophilic Polymer Coating" ( $\mathrm{pHPC}$ ), which was originally developed for NiTi implants, decrease the thrombogenicity of metal surfaces. In this study, the transferability of pHPC onto biomedical CoCr-based alloys is examined. Coated surfaces were characterized via contact-angle measurement and atomic force microscopy. The equivalence of the antithrombogenic effect in contact with whole human blood was demonstrated in vitro for CoCr plates compared to NiTi plates on a platform shaker and for braided devices in a Chandler loop. Platelet adhesion was assessed via scanning electron microscopy and fluorescence microscopy. The coating efficiency of $\mathrm{pHPC}$ on $\mathrm{CoCr}$ plates was confirmed by a reduction of the contact angle from $84.4^{\circ} \pm 5.1^{\circ}$ to $36.2^{\circ} \pm 5.2^{\circ}$. The surface roughness was not affected by the application of pHPC. Platelet adhesion was significantly reduced on $\mathrm{pHPC}$-coated specimens. The platelet covered area was reduced by $85 \%$ for coated CoCr plates compared to uncoated samples. Uncoated braided devices were completely covered by platelets, while on the pHPC-coated samples, very few platelets were visible. In conclusion, the antithrombogenic effect of pHPC coating can be successfully applied on CoCr plates as well as stent-like CoCr braids.
\end{abstract}

Keywords: antithrombogenic; endovascular implants; surface modifications; platelet adhesion; hydrophilic polymer coating; shape memory alloys; biomaterials; $\mathrm{CoCr}$ alloys; medical devices

\section{Introduction}

Ischemic and hemorrhagic vascular diseases (e.g., myocardial infarct, stroke, atherosclerosis) are among the most frequent causes of death in Western countries [1]. Today, metallic implants are the mainstay of endovascular therapy, which is true for peripheral, cardiologi$\mathrm{cal}$, and neurovascular interventions. For the purpose of vessel occlusion, device-induced thrombus formation is desired, but when it comes to vessel reconstruction, the inherent thrombogenicity of stents and their derivates is an issue [2,3].

Extended research in the field of endovascular treatments of diseases has brought forth a large variety of devices designed for many purposes. While the designs of stents and flow diverters vary significantly, the most commonly used materials today are NiTi alloys, $\mathrm{CoCr}$ alloys, or medical-grade steel due to their excellent biocompatibility and mechanical properties [4].

However, once exposed to blood, endovascular implants with a bare metal surface trigger the adhesion of plasma proteins and activate both the coagulation cascade and 
surrounding thrombocytes. Thrombus formation may result, eventually causing local and distal vessel occlusion [5-8].

The previous paradigm for dealing with this issue comprised the modification of the coagulation system and the platelet function of the patient who is supposed to receive the device implant. Medications that interfere with the various platelet receptors are given according to complex regimens. Typically, the standard of care to prevent thrombus formation on vascular implants is a dual antiplatelet therapy (DAPT) with acetylsalicylic acid (ASA) and Clopidogrel, followed by monotherapy with ASA only, which is often continued for the rest of the patient's life $[9,10]$.

DAPT was and remains, for the time being, the cornerstone of stenting. However, its action is, to a certain degree, unpredictable, subject to several interactions, and difficult to test [11]. Clinical complications may result from hypo- or hyperresponse of patients to the same standard dosage. While DAPT does effectively lower the risk of vessel occlusion in most patients, it simultaneously increases the risk of hemorrhagic events, especially in the first year after implantation [7,8,12-17]. Finally, the emergency treatment of endovascular diseases is severely limited, as effective platelet inhibition should ideally start a few days prior to treatment. Especially in the case of hemorrhagic emergency (e.g., subarachnoid hemorrhage after rupture of an intracranial aneurysm), early treatment is necessary to prevent cerebral infarction, meaning that the application of antiplatelet agents might not be recommended due to the increased risk of rebleeding [18].

Many attempts have been made to avoid this dilemma. There is a large variety of biodegradable or drug-eluting stents with promising results that improved the situation, but did not make DAPT obsolete $[19,20]$.

Some more recent approaches have aimed to reduce the thrombogenicity of the implant surface itself with coatings or surface modifications that disguise the foreign material as endogenous. Efforts to develop such a surface modification have existed for many years. Promising results were obtained in vitro, but most of these were limited to ideal substrates like glass or carefully polished metal or polymer slides. Technical surfaces and the highly complex forms of medical implants seem to hold more challenges regarding antithrombogenicity [21-24]. Other approaches have managed to shorten the time that DAPT is necessary by inducing faster endothelialization (e.g., the COBRA coronary stent with Polyzene-F coating), but do not solve the problems with non-responders or when emergency treatment is required [25].

Currently, only two coatings seem to follow a "bio-mimicry" approach on actual devices: Medtronic's "Shield" technology and phenox's "Hydrophilic Polymer Coating" (pHPC). The Shield technology is available on Medtronic's Pipeline Flex Embolization Device (PED) with Shield Technology (PED Shield). pHPC is currently available on the pCONUS HPC Bifurcation Aneurysm Implant and on the p48 MW HPC and p64 MW HPC flow diverters. All devices are indicated for the treatment of intracranial aneurysms.

The Shield technology is a synthetic phosphorylcholine polymer that is naturally present on the surface of erythrocytes [26,27].

PED Shield implants have been shown to cause fewer thrombogenic effects compared to other uncoated flow diverters in vitro and ex vivo. However, clinical data do not show successful usage of the PED Shield under monotherapy [27-30].

pHPC is a coating technology developed by phenox $\mathrm{GmbH}$, Bochum, Germany, and has demonstrated effective antithrombogenic properties in vitro and in human approaches when applied to NiTi surfaces of laser-cut or braided implants [31,32].

The successful and effective antithrombogenic "disguise" of devices would be a significant advancement for all applications where foreign materials come in contact with blood. That is why it is of utmost interest if pHPC can be applied to materials other than NiTi that are commonly used for devices in blood contact. While NiTi exhibits a surface oxide mainly consisting of $\mathrm{TiO}_{2}$, for CoCr alloys, the high amount of $\mathrm{Cr}$ is responsible for the formation of a thick oxide layer that mostly consists of $\mathrm{Cr}_{2} \mathrm{O}_{3}$ [33]. 
Therefore, the purpose of this study was to evaluate the compatibility of pHPC with CoCr-alloy substrates. The coating efficiency, quality, and (anti)thrombogenicity of pHPC on $\mathrm{CoCr}$ substrates was examined by means of dynamic contact-angle (CA) measurement, atomic force microscopy (AFM), in vitro testing, fluorescence microscopy, and scanning electron microscopy (SEM).

\section{Materials and Methods}

\subsection{Specimens and Coating}

Coated and uncoated specimens that were manufactured from two commercially pure, biomedical-grade CoCr-based alloys were analyzed. In particular, plates made from L-605 (CoCr-based alloy, ASTM F90) and flow-diverter-like braids made from 35NLT wires (CoCr-based alloy, ASTM F562) served as substrates for different tests. L-605 is a Co-basedalloy with chromium $(\mathrm{Cr})$, tungsten $(\mathrm{W})$, and nickel $(\mathrm{Ni})$ as the main alloying elements. The 35NLT braid resembles the design of the p48 MW (HPC), and was used to compare the coating efficiency and antithrombogenicity of $\mathrm{pHPC}$ on a flow diverter made of $\mathrm{CoCr}$ wires. 35NLT is a Co-based-alloy with $\mathrm{Ni}, \mathrm{Cr}$, and molybdenum (Mo) as the main alloying elements [34]. Both $\mathrm{CoCr}$ alloys are standard materials for medical applications and are already in use for stents, flow diverters, or artificial heart valves $[35,36]$.

NiTi plates and p48 MW or p48 MW HPC implants (provided by phenox GmbH, Bochum, Germany) were used as references to compare the performance of the antithrombogenic pHPC coating on CoCr and NiTi alloys. The test plates $(9 \times 9 \times 0.5 \mathrm{~mm})$ were laser-cut, pickled, electropolished, and passivated to create a homogenous, shiny surface resembling that of laser-cut stents made of CoCr or NiTi alloys. Subsequently, the specimens were coated with the antithrombogenic $\mathrm{pHPC}$ by phenox $\mathrm{GmbH}$.

pHPC is a newly developed glycan-based multilayer polymer mimicking the glycocalyx from the natural outer layer on cells. As the outer layer of endothelial cells, the glycocalyx forms the inner lining of blood vessels. On NiTi surfaces, the pHPC's thickness ranges between 5 and $20 \mathrm{~nm}$, as estimated by X-ray photoelectron spectroscopy [31,37]. The application process and the thin nature of the coating do not influence the physical and mechanical properties of the devices that it is applied to.

\subsection{Coating Efficiency-Wettability}

In the literature, the antithrombogenic pHPC coating is known to change the wettability of NiTi surfaces, and can therefore be used as an indicator for the coating efficiency [31]. Thus, in this study, the wettability and hydrophilicity of the plates were measured using a modified Wilhelmy Plate method in a tensiometer (DCAT 21, DataPhysics Instruments $\mathrm{GmbH}$, Stuttgart, Germany) through immersion of the sample plates in pure water. The dynamic contact angle was derived from the weight change during immersion, as water will form a larger lamella when the specimens are more hydrophilic. The CAs of the NiTi $(n=10)$ and $\operatorname{CoCr}(n=10)$ plates were measured before and after the coating of the samples.

\subsection{Atomic Force Microscopy}

AFM of coated and uncoated NiTi and CoCr plates was performed on a Dimension FastScan AFM (Bruker, Billerica, MA, USA) to characterize the topographic nature of the plates before and after coating. An area of $1 \times 1 \mu \mathrm{m}$ was scanned on each sample, and the surface analysis was assessed through determination of the mean arithmetic roughness value, Ra, from three randomly chosen line scans (length of $1 \mu \mathrm{m}$ each).

\subsection{In Vitro Blood Contact}

Blood sampling was performed under the approval of the ethics commission of the Faculty of Medicine of the Ruhr Universität Bochum, Germany (registration number: 16-5991). Informed consent was obtained from all individual participants included in the study. All procedures performed in studies involving human participants were in accordance with 
the ethical standards of the institutional and/or national research committee and with the 1964 Helsinki Declaration and its later amendments or comparable ethical standards.

For in vitro testing, the plates were incubated under dynamic conditions on a shaker in heparinized human venous blood. The blood was collected from 10 voluntary and healthy donors. An abnormal blood count measured via a hematology analyzer (KM-21 N, Sysmex, Nordersted, Germany) and the intake of drugs interfering with blood coagulation were exclusion criteria for participation in the study. All steps were performed under sterile conditions. The plates were rinsed twice in phosphate-buffered saline (PBS) before blood contact. Afterwards, they were incubated under dynamic conditions in 24-well plates in $2 \mathrm{~mL}$ blood on a shaker (speed level 4; Titramax 100, Heidolph Instruments, Schwabach, Germany). After 10 min of incubation, non-adherent cells were removed by rinsing the specimens with PBS.

The stent devices were incubated in a modified Chandler loop flow model. Blood was collected with the "S-Monovette Blood collection system" (Sarsted, Nümbrecht, Germany). An abnormal blood count measured via a hematology analyzer (KM-21 N, Sysmex, Nordersted, Germany) and the intake of drugs interfering with blood coagulation were exclusion criteria for participation in the study. The devices were deployed in PVC tubes (Rehau, Erlangen, Germany) with an inner diameter of $3 \mathrm{~mm}$. The tubes were first rinsed with PBS and filled with $2 \mathrm{~mL}$ of blood, leaving an air bubble of $1 \mathrm{~mL}$ inside the tube; then, the tube's ends were interconnected, forming loops. The loops were then rotated at a rate of 30 rotations per minute in a water bath at $37^{\circ} \mathrm{C}$ for $120 \mathrm{~min}$. The rotation speed resulted in a flow volume of $60 \mathrm{~mL} / \mathrm{min}$ and a flow velocity of $90 \mathrm{~mL} / \mathrm{min}$ (due to the air bubble), thereby resembling typical flow rates in the vertebral artery [38]. The blood count was again performed after incubation.

\subsection{CD61 Immunohistochemistry}

CD61 (integrin b-3) is a glycoprotein found on the surface of platelets. CD61+ adherent platelets were stained using CD61-PE antibody (BD Pharmingen, Heidelberg, Germany) fluorescence staining. After incubation in whole blood, the specimens were rinsed with PBS twice in order to remove non-adherent cells. The antibody was diluted 1:5 in PBS and added to the specimens. After $15 \mathrm{~min}$ incubation in the dark, specimens were rinsed with PBS twice, fixed with $1 \%$ paraformaldehyde (Sigma-Aldrich, Taufkirchen, Germany) in PBS, and analyzed using a fluorescence microscope (Olympus BX40, Olympus, Hamburg, Germany) equipped with a digital camera (Moticam 5, Motic, Wetzlar, Germany).

\subsection{Semi-Quantitative Phase Analyses}

Platelet adherence was assessed by analyzing the platelet-covered area of the plates using ImageJ software (National Institutes of Health, Bethesda, MD, USA). Four defined areas of interest per plate $\left(0.06 \mathrm{~mm}^{2}\right.$ each, total $\left.0.24 \mathrm{~mm}^{2}\right)$ were examined. The results were reported as the percentage of positively stained area by relating the positively stained area (CD61+ stained cells) with the absolute area of the regions of interest.

\subsection{Scanning Electron Microscopy}

To examine the level of platelet activation and clot formation on the stent devices, SEM examinations were performed after incubation in the Chandler loop on the same specimens used for fluorescence imaging.

After incubation, the specimens were prepared for SEM examination by rinsing with PBS twice, fixing with 3.7\% glutaraldehyde (Sigma-Aldrich, Taufkirchen, Germany) in PBS for $15 \mathrm{~min}$, dehydrating with an ascending series of alcohols, drying for $24 \mathrm{~h}$ at room temperature, and, finally, sputtering with gold (Edwards Sputter Coater S150B9, Edwards Limited, Crawley, UK).

SEM was performed on an LEO 1530 Gemini (Carl Zeiss AG, Jena, Germany). 


\subsection{Statistical Analysis}

Data from platelet activation were analyzed with the Mann-Whitney test. If a significant difference was found, treated groups were compared with the control group by using Dunn's post-test. GraphPad Prism software (version 3.03; GraphPad Software Inc., La Jolla, CA, USA) was used for the analysis. $p$-values of less than 0.05 were considered statistically significant. The data of the surface roughness was assessed by determining the average Ra for three individual lines per scan. Results are presented as 'mean \pm standard error of the mean' (mean $\pm \mathrm{SE}$ ).

\section{Results}

\subsection{Surface Analysis-Wettability and Surface Topography}

The results of the CA measurement are given in Table 1 . The CAs were $78.1^{\circ} \pm 4.8^{\circ}$ for the uncoated NiTi specimens and $84.4^{\circ} \pm 5.1^{\circ}$ for the uncoated $\mathrm{CoCr}$ specimens. After functionalization with $\mathrm{pHPC}$, the $\mathrm{CAs}$ of $\mathrm{CoCr}$ and NiTi plates were decreased by roughly $45^{\circ}-50^{\circ}$ (CA of $31.6^{\circ} \pm 2.2^{\circ}$ for the NiTi plates, $36.2^{\circ} \pm 5.2^{\circ}$ for the CoCr plates).

Table 1. Contact angle (CA) and arithmetic roughness of coated and uncoated NiTi and $\mathrm{CoCr}$ specimens.

\begin{tabular}{ccccc}
\hline Specimen & $\begin{array}{c}\text { NiTi Plate } \\
\text { Uncoated }\end{array}$ & $\begin{array}{c}\text { NiTi Plate pHPC } \\
\text { Coated }\end{array}$ & $\begin{array}{c}\text { CoCr Plate } \\
\text { Uncoated }\end{array}$ & $\begin{array}{c}\text { CoCr Plate } \\
\text { pHPC Coated }\end{array}$ \\
\hline Contact Angle $(\mathrm{CA})\left[^{\circ}\right]$ & $78.1 \pm 4.8$ & $31.6 \pm 2.2$ & $84.4 \pm 5.1$ & $36.2 \pm 5.2$ \\
Average roughness $(\mathrm{Ra})[\mathrm{nm}]$ & $0.383 \pm 0.094$ & $0.214 \pm 0.020$ & $0.029 \pm 0.002$ & $0.036 \pm 0.001$ \\
\hline
\end{tabular}

Figure 1 shows representative AFM images of the uncoated (Figure 1a,c) and coated specimens (Figure 1b,d). Microscopically, the surface of the NiTi plates had a homogeneous surface with a honeycomb-like structure and minimal waviness. The evenly distributed peaks were about $50 \mathrm{~nm}$ apart and had an altitude of about $8 \mathrm{~nm}$. The CoCr plates had a homogenous surface profile with peaks of less than $0.2 \mathrm{~nm}$ height and a spacing of less than $10 \mathrm{~nm}$, with some slight waviness. The corresponding results of a nanoscopic analysis of the mean arithmetic roughness values (Ra) are given in Table 1. The coating of the specimens did not alter the homogenous surface profile compared to the corresponding uncoated specimens.

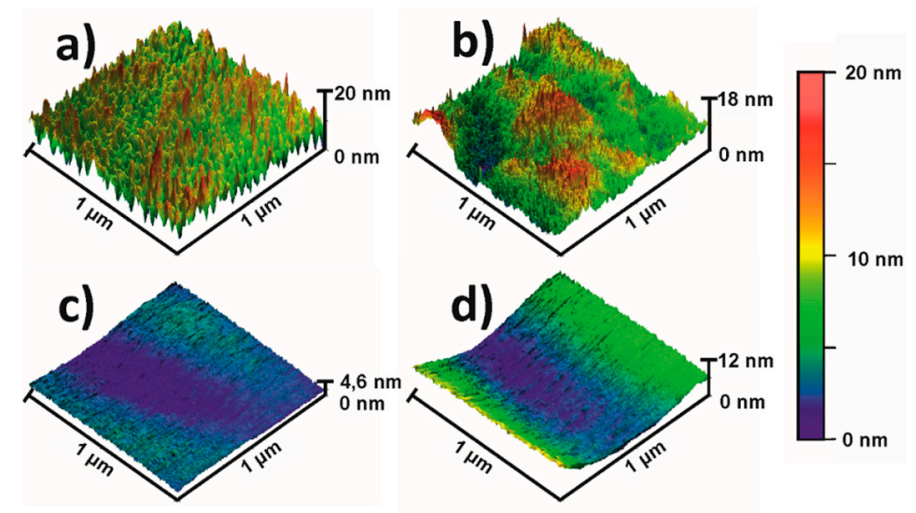

Figure 1. Representative atomic force microscopy (AFM) images of the uncoated (a) and coated (b) NiTi plates and the uncoated (c) and coated (d) CoCr plates.

\subsection{Thrombogenicity—Fluorescence and SEM Imaging}

Figure 2 shows the representative fluorescence microscopic images of pHPC-coated (Figure $2 \mathrm{~b}, \mathrm{~d}$ ) and uncoated (Figure 2a,c) NiTi and CoCr plates, which were incubated in vitro in human blood and stained with CD61 antibody. Few CD61+ platelets were detected on the coated specimens (yellow fluorescence), whereas the uncoated specimens were homogenously covered with cells in each experiment. 

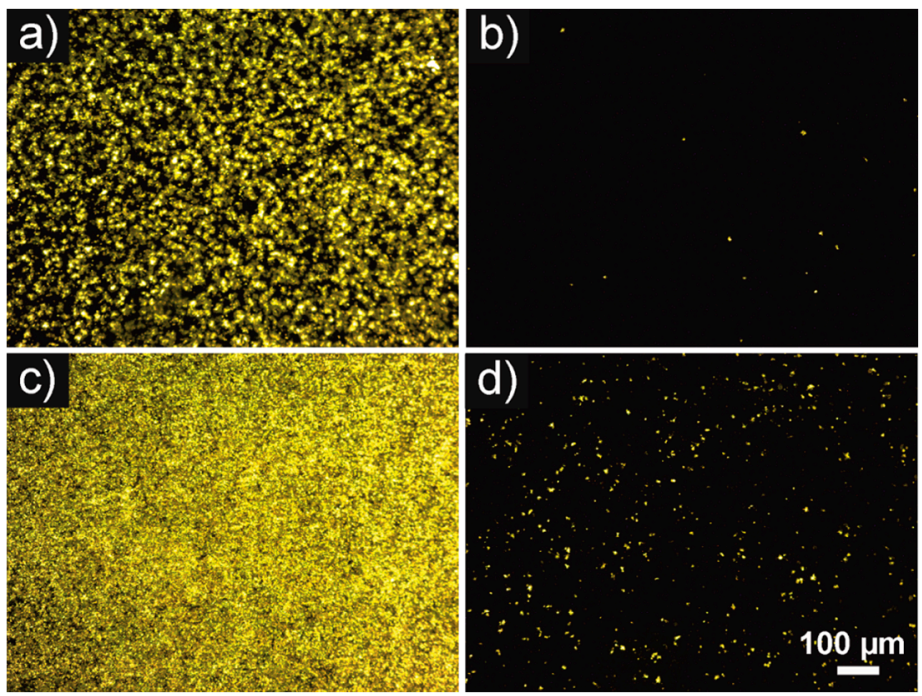

Figure 2. Representative fluorescence micrographs of uncoated $(\mathbf{a}, \mathbf{c})$ and phenox's "Hydrophilic Polymer Coating" (pHPC)-coated (b,d) NiTi $(\mathbf{a}, \mathbf{b})$ and $\mathrm{CoCr}(\mathbf{c}, \mathbf{d})$ specimens. The plates were incubated in whole human blood for $10 \mathrm{~min}$ under dynamic conditions. Adherent platelets were stained with a CD61 antibody (yellow fluorescence). (Scale bar for all images $100 \mu \mathrm{m}$.)

Figure 3 shows the results of the quantitative phase analysis of the platelet-covered area on the plates. The amount of surface area covered with adhering thrombocytes was significantly lower on the pHPC-coated NiTi and CoCr plates compared to the uncoated ones. Overall, the CoCr plates did elicit more platelet activation than the NiTi plates. Uncoated CoCr specimens were covered with CD61+ platelets by $85.5 \% \pm 10.7 \%$, while the uncoated NiTi specimens were covered by $66.9 \% \pm 21.5 \%$. The pHPC-coated CoCr plates were covered by $12.8 \% \pm 9.4 \%$ and the coated NiTi plates by $6.7 \% \pm 8.8 \%$. On average, the platelet adherence was reduced by $90 \%$ on coated $\mathrm{NiTi}$ and by $85 \%$ on the pHPC-coated CoCr specimens.

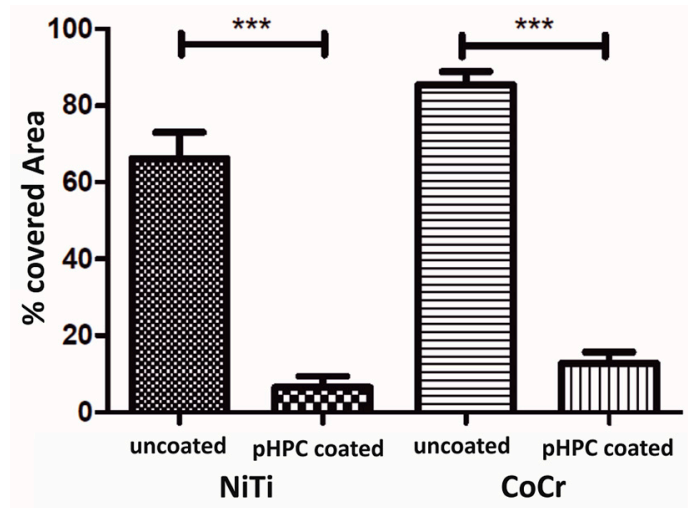

Figure 3. Quantitative phase analysis of the area coated with CD61+ cells from experiments with ten different donors (mean $\pm \mathrm{SE}$; asterisks denote significance at ${ }^{* * *} p \leq 0.001$; Mann-Whitney and Dunn's post-test; sample size uncoated vs. coated $n=10$ ). While significantly fewer CD61+ platelets adhered to the coated specimens than to the uncoated ones, there is no significant difference between the NiTi and the CoCr specimens.

Additionally, stent devices were incubated in a modified Chandler loop flow model with whole human blood for $120 \mathrm{~min}$, and adherent cells were again stained with a CD61 antibody and analyzed using fluorescence microscopy.

Figure 4 shows representative fluorescence micrographs of uncoated and pHPC-coated p48 MW (NiTi) and CoCr braids. While the uncoated devices were completely covered with 
adherent platelets, there were considerably fewer fluorescent cells on the pHPC-coated braids. On both the p48 MW HPC and the coated CoCr braids, the adherent cells tended to adhere to contact points where the wires of the braids crossed over each other.

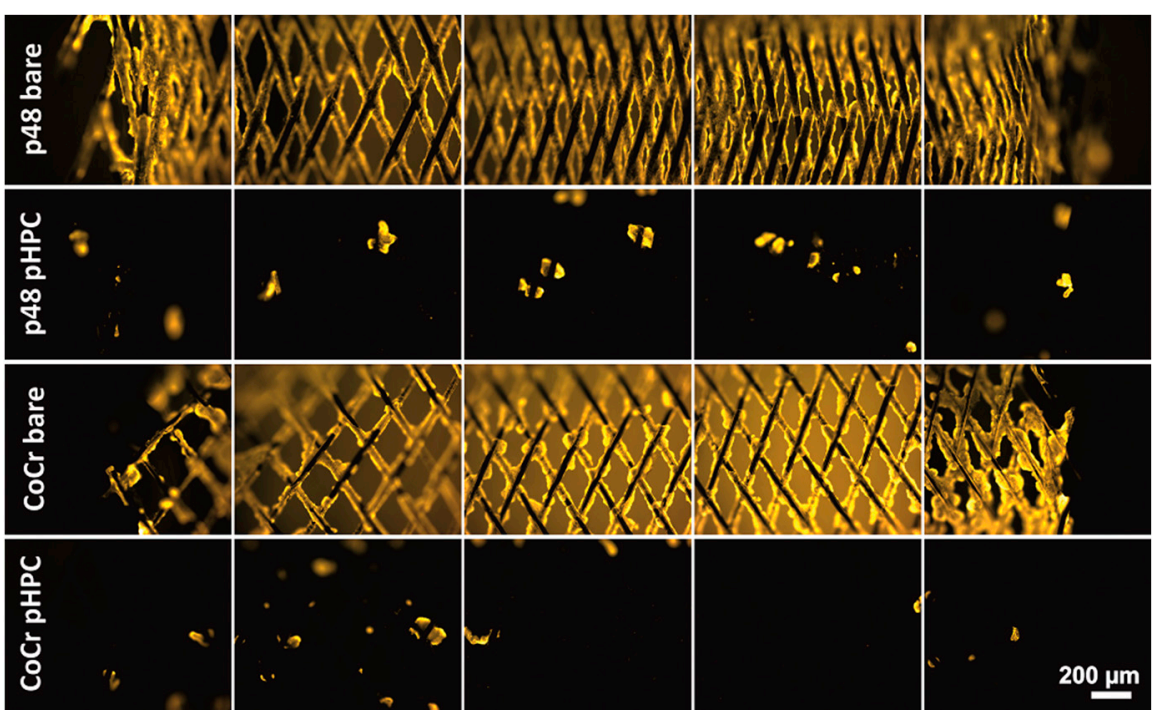

Figure 4. Representative fluorescence micrographs of uncoated and pHPC-coated p48 MW and CoCr specimens. The devices were incubated in whole human blood in a modified Chandler loop flow model under dynamic conditions at $37^{\circ} \mathrm{C}$ for $120 \mathrm{~min}$. Adherent platelets were stained with a CD61 antibody (yellow fluorescence). Though the uncoated devices were completely covered with adherent platelets, there were considerably fewer fluorescent cells on the pHPC-coated braids. (Scale bar for all images $200 \mu \mathrm{m}$.)

Figure 5 shows representative SEM images of the respective stent devices after incubation in the Chandler loop. The wires of the uncoated devices (Figure 5a,c,e,g) were completely covered by a dense layer of fibrin and embedded platelets. In contrast, only a few platelets were visible on the pHPC-coated samples (Figure 5b,d,f,h). Again, the predominant adherence of platelets at the crossings of the wires on the coated devices was observed.

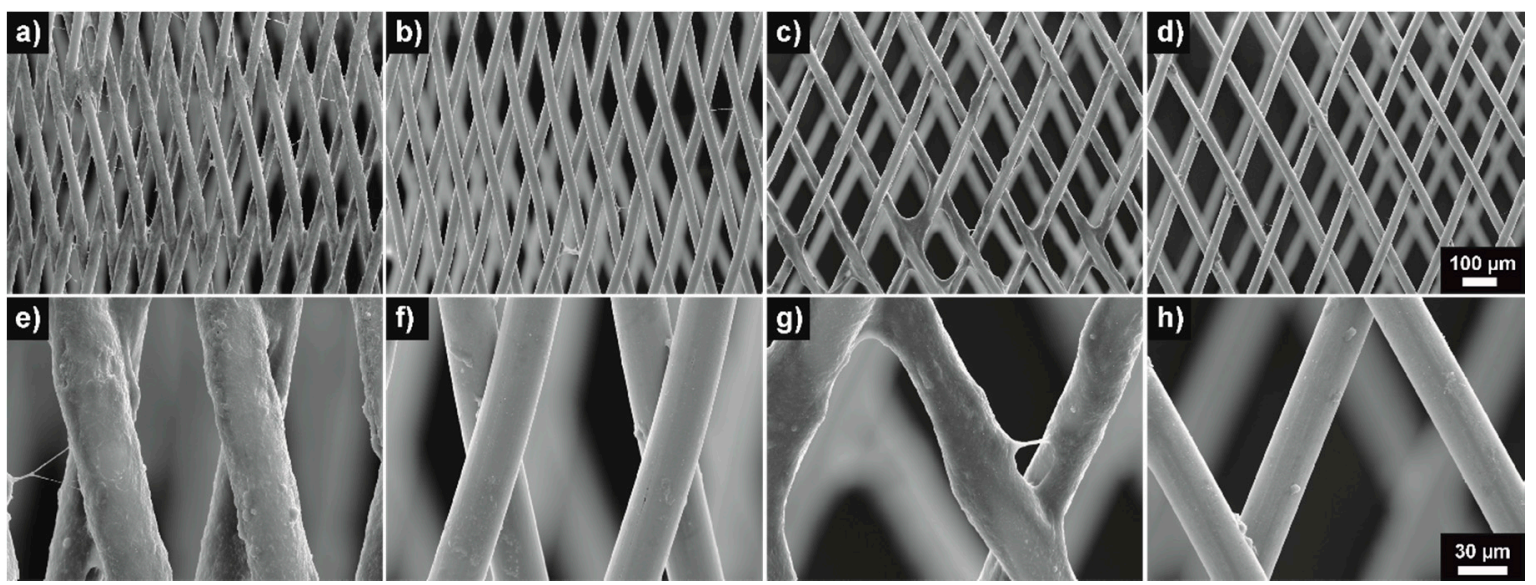

Figure 5. Representative scanning electron microscopy (SEM) images (in secondary electron contrast) of coated (b,d,f, $\mathbf{h})$ and uncoated $(\mathbf{a}, \mathbf{c}, \mathbf{e}, \mathbf{g}) \mathrm{NiTi}(\mathbf{a}, \mathbf{b}, \mathbf{e}, \mathbf{f})$ and $\mathrm{CoCr}(\mathbf{c}, \mathbf{d}, \mathbf{g}, \mathbf{h})$ devices after incubation in whole human blood in a modified Chandler loop flow model under dynamic conditions at $37^{\circ} \mathrm{C}$ for $120 \mathrm{~min}$. The uncoated devices were completely covered with adherent platelets and fibrin clots, while only a few cells adhered to the pHPC-coated devices. (Scale bar for the upper row $100 \mu \mathrm{m}$, scale bar for the lower row $30 \mu \mathrm{m}$.) 


\section{Discussion}

pHPC was originally developed for surface modification of NiTi devices and is approved and available on endovascular stent devices made from NiTi. However, the most commonly used materials for similar applications, apart from NiTi alloys, are $\mathrm{CoCr}$ alloys and medical-grade steel [4]. While NiTi exhibits a surface oxide that mainly consists of $\mathrm{TiO}_{2}$, for $\mathrm{CoCr}$ alloys, the high amount of $\mathrm{Cr}$ is responsible for the formation of a thick oxide layer that mostly consists of $\mathrm{Cr}_{2} \mathrm{O}_{3}$ [33]. Hence, the purpose of this study was to evaluate the compatibility of pHPC with CoCr-alloy substrates to expand the range of antithrombogenic biomaterials that are commonly used in blood contact. Therefore, the coating efficiency, quality, and (anti)thrombogenicity of pHPC on CoCr substrates was examined by means of dynamic contact-angle (CA) measurement, atomic force microscopy (AFM), in vitro testing, fluorescence microscopy, and scanning electron microscopy (SEM).

The platelet activation and adhesion were significantly reduced on pHPC-coated $\mathrm{CoCr}$ specimens compared to the corresponding uncoated specimens (Figures 2-4). The surface area covered by adherent platelets was reduced by $85 \%$ on the pHPC-coated $\mathrm{CoCr}$ plates compared to a reduction by $90 \%$ on coated NiTi (Figure 3). This is also true for pHPCcoated NiTi and $\mathrm{CoCr}$ braids when tested under dynamic conditions in a Chandler loop experiment (Figures 4 and 5). It is known that the thrombogenicity of a surface depends on the preceding adhesion of proteins [39]. In turn, the adhesion of proteins depends on the surface topography and wettability [40].

The surface topography of a biomaterial's surface has been shown to have a great impact on the adherence and proliferation of proteins and, thereby, cells; therefore, it is of interest regarding platelet activation and endothelialization of vascular implants [40]. The microscopic and nanoscopic surface structure was apparently unaffected by the coating (Table 1, Figure 1). The NiTi plates were very smooth and had a consistent surface structure, typical for electropolished NiTi [41], while the CoCr plates were even smoother. The surface structures of the NiTi and CoCr samples were not microscopically or macroscopically affected by the coating. The coating is known to be extremely thin $(<10 \mathrm{~nm})$ on NiTi [31] and apparently formed the same way on $\mathrm{CoCr}$, as the coating procedure did not affect the original surface. The smooth surfaces of the plates resembled those of typical bare metal stents, which are also usually electropolished to deburr the edges and to create a smooth surface finish after laser cutting, thereby lowering the likelihood of a foreign body response by blood or vessel cells [42,43].

While the pHPC coating does not affect the topography of the NiTi and CoCr plates, it certainly does affect the wettability (Table 1).

The CAs of the uncoated plates can be considered as weakly hydrophilic, with $78.1^{\circ} \pm 4.8^{\circ}$ for the NiTi surface and $84.4^{\circ} \pm 5.1^{\circ}$ for the CoCr surface (Table 1) [44] After functionalization of the surfaces using the pHPC coating, the decrease of the CA by roughly $45^{\circ}$ to $50^{\circ}$ resulted in a moderately hydrophilic surface (CA of $36.2^{\circ} \pm 5.2^{\circ}$ for the $\mathrm{CoCr}$ plates and $31.6^{\circ} \pm 2.2^{\circ}$ for the NiTi plates—see Table 1$)$, thereby indicating successful coating of both materials.

A biomaterial's wettability is known to influence the adhesion of proteins and, thereby, to influence the interaction with cells [45]. However, the wettability of devices is of interest for further reasons. The adhesion of proteins is known to be the start of cell-surface interaction [46]. Firstly, thrombocyte activation and adhesion might be affected by a changed wettability on the surface of implants designed to treat vascular disease, and secondly, the proliferation of endothelial cells might be enhanced or decreased due to the same effect. A moderate wettability with CAs of around $35^{\circ}$ can be considered optimal for devices that are in contact with blood. Protein adsorption to surfaces is the beginning of all cell-surface interactions. Extremely hydrophilic $\left(\mathrm{CA}<25^{\circ}\right)$ or hydrophobic surfaces $\left(\mathrm{CA}>85^{\circ}\right)$ do reduce protein adsorption and, thereby, reduce cell-surface interaction in general [45]. Platelet activation and adherence are known to be decreased by increasing wettability [47-49]. However, endothelialization, which is important for the long-term biocompatibility of endovascular devices, is decreased on extremely hydrophilic or hy- 
drophobic surfaces due to the reduced adhesion of extracellular matrix proteins (EMPs). Moderately hydrophilic surfaces, like pHPC-coated NiTi or CoCr surfaces, however, do allow the adherence of extracellular matrix proteins (and, therefore, endothelialization), with a maximum endothelial cell adhesion occurring at a CA of $35^{\circ}$ to $50^{\circ}[45,50]$.

This is in line with the observations from our three animal studies. In those studies, pHPC-coated and uncoated specimens were implanted in the carotid arteries of New Zealand white rabbits for 30 and $120 \mathrm{~d}$. It was shown that pHPC coating of NiTi surfaces does not delay the ingrowth of stent devices into the vessel wall [51,52]. The antithrombogenic effect of pHPC has been shown to last long enough after implantation to keep patients under ASA monotherapy until the device is completely incorporated by endothelial cells [32]. If this is true for $\mathrm{CoCr}$ substrates as well still needs to be examined in further research.

Overall, the antithrombogenic effect of pHPC was successfully applied to two different medical CoCr alloys (plates from L-605 and flow-diverter-like stent devices from 35NLT wires). The transfer onto other materials for biomedical applications might be of interest for further research. The remaining platelets on the coated stent devices were predominantly observed at the contact points of the crossings of wires. This has been observed before on braided devices after implantation in animals and humans, and is mainly caused by additional turbulence at these points, as platelets are activated by additional sheer stress [53-55].

However, the surfaces of medical-grade $\mathrm{CoCr}$ alloys and stainless steels are effectively alike. While NiTi exhibits a surface oxide mainly consisting of $\mathrm{TiO}_{2}$, for $\mathrm{CoCr}$ alloys and stainless steel, the high amount of $\mathrm{Cr}$ is responsible for the formation of a thick oxide layer that mostly consists of $\mathrm{Cr}_{2} \mathrm{O}_{3}$ [33]. pHPC might, therefore, be effortlessly transferred onto stainless steel devices as well.

Even though the results are promising, further experiments regarding the coating's mechanical and biological durability on CoCr surfaces might be of further interest. However, these properties need to be evaluated under consideration of the actual application because, e.g., different implant designs might generate different loads, have different surface properties, or hold other challenges.

\section{Conclusions}

The conducted experiments demonstrate the transferability of the pHPC technology onto two different $\mathrm{CoCr}$ alloys for biomedical applications. The coating was successfully applied to plates and braided wires without negatively affecting the materials' surface quality. Furthermore, the platelet adhesion was significantly reduced on coated NiTi and $\mathrm{CoCr}$ devices compared to uncoated devices. The results of this study show that antithrombogenic pHPC coating is a promising candidate for the development of endovascular devices of different materials with antithrombogenic surface properties.

\section{Patents}

Patent "Beschichtung für Medizinprodukte" pending under the application numbers DE 102017111486 A1, DE 102017011956 A1, and WO 002018210989 A1.

Author Contributions: Conceptualization, C.B., T.L.-H. and H.H.; Formal analysis, C.B. and M.P.; Investigation, C.B. and M.P.; Project administration, T.L.-H.; Resources, W.T. and H.M.; Supervision, V.T., S.S., S.W., W.T., H.H. and H.M.; Validation, C.B., T.L.-H. and M.P.; Visualization, C.B. and T.L.-H.; Writing-original draft, C.B.; Writing—review and editing, C.B., T.L.-H., J.L., H.H. and H.M. All authors have read and agreed to the published version of the manuscript.

Funding: This research received no external funding.

Institutional Review Board Statement: The study was conducted according to the guidelines of the Declaration of Helsinki and approved by the Ethics Committee of the Faculty of Medicine of the Ruhr Universität Bochum, Germany (protocol code 16-5991, 06.04.2017).

Informed Consent Statement: Informed consent was obtained from all subjects involved in the study. 
Data Availability Statement: The data that support the findings of this study are available from the corresponding author, C.B., upon reasonable request.

Conflicts of Interest: C.B., T.L.-H., and V.T.: Employee in the R\&D department of phenox GmbH; Dr.-Ing. J.L.: Consultant of phenox; PD Dr. rer. nat. M.P.: Institution received research grants from phenox GmbH; Dr.-Ing. S.S., Prof. Dr.-Ing. S.W., and Prof. Dr.-Ing. W.T.: No conflict of interest declared; Prof. Dr. med. Dr. h.c. H.H.: Co-founder and shareholder of phenox GmbH; Prof. Dr.-Ing. H.M.: Co-founder, shareholder, and CEO of phenox GmbH.

\section{References}

1. Bundesamt, S. Gesundheit_-Todesursachen in Deutschland; Statistisches Bundesamt: Wiesbaden, Germany, 2015.

2. Leon, M.B.; Baim, D.S.; Popma, J.J.; Gordon, P.C.; Cutlip, D.E.; Ho, K.K.; Giambartolomei, A.; Diver, D.J.; Lasorda, D.M.; Williams, D.O.; et al. A clinical trial comparing three antithrombotic-drug regimens after coronary-artery stenting. Stent anticoagulation restenosis study investigators. N. Engl. J. Med. 1998, 339, 1665-1671. [CrossRef] [PubMed]

3. Dotter, C.T. Transluminally-placed coilspring endarterial tuve grafts: Long term patency in canine popliteal artery. Investig. Radiol. 1969, 4, 329-332. [CrossRef] [PubMed]

4. Machraoui, A.; Grewe, P.; Fischer, A. Koronarstenting. Werkstofftechnik, Pathomorphologie, Therapie; Steinkopff: Heidelberg, Germany, 2001; ISBN 978-3-642-57637-9.

5. Gorbet, M.B.; Sefton, M.V. Biomaterial-associated thrombosis: Roles of coagulation factors, complement, platelets and leukocytes. Biomaterials 2004, 25, 5681-5703. [CrossRef] [PubMed]

6. Mikhalovska, L.I.; Santin, M.; Denyer, S.P.; Lloyd, A.W.; Teer, D.G.; Field, S.; Mikhalovsky, S.V. Fibrinogen adsorption and platelet adhesion to metal and carbon coatings. Thromb. Haemost. 2004, 92, 1032-1039. [CrossRef]

7. Versteeg, H.H.; Heemskerk, J.W.M.; Levi, M.; Reitsma, P.H. New fundamentals in hemostasis. Physiol. Rev. 2013, 93, 327-358. [CrossRef] [PubMed]

8. Reininger, A.J. Function of von Willebrand factor in haemostasis and thrombosis. Haemophilia 2008, 14, 11-26. [CrossRef]

9. Honda, Y.; Fitzgerald, P.J. Stent thrombosis: An issue revisited in a changing world. Circulation 2003, 108, 2-5. [CrossRef]

10. Kastrati, A.; Schühlen, H.; Hausleiter, J.; Zitzmann-Roth, E. Restenosis after coronary stent placement and randomization to a 4-week combined antiplatelet or anticoagulant therapy: Six-month angiographic follow-up of the intracoronary stenting and antithrombotic regimen (ISAR) trial. Circulation 1997, 96, 462-467.

11. Martinez-Moreno, R.; Aguilar, M.; Wendl, C.; Bäzner, H.; Ganslandt, O.; Henkes, H. Fatal thrombosis of a flow diverter due to ibuprofen-related antagonization of acetylsalicylic acid. Clin. Neuroradiol. 2016, 26, 355-358. [CrossRef]

12. Berger, P.B.; Bhatt, D.L.; Fuster, V.; Steg, P.G.; Fox, K.A.A.; Shao, M.; Brennan, D.M.; Hacke, W.; Montalescot, G.; Steinhubl, S.R.; et al. Bleeding complications with dual antiplatelet therapy among patients with stable vascular disease or risk factors for vascular disease: Results from the clopidogrel for high atherothrombotic risk and ischemic stabilization, management, and avoidance (CHARISMA) trial. Circulation 2010, 121, 2575-2583. [CrossRef]

13. Hankey, G.J.; Eikelboom, J.W. Aspirin resistance. Lancet 2006, 367, 606-617. [CrossRef]

14. Nguyen, T.A.; Diodati, J.G.; Pharand, C. Resistance to clopidogrel: A review of the evidence. J. Am. Coll. Cardiol. 2005, 45, 1157-1164. [CrossRef] [PubMed]

15. Farid, N.A.; Kurihara, A.; Wrighton, S.A. Metabolism and disposition of the thienopyridine antiplatelet drugs ticlopidine, clopidogrel, and prasugrel in humans. J. Clin. Pharmacol. 2010, 50, 126-142. [CrossRef] [PubMed]

16. Dobesh, P.P.; Oestreich, J.H. Ticagrelor: Pharmacokinetics, pharmacodynamics, clinical efficacy, and safety. Pharmacotherapy 2014, 34, 1077-1090. [CrossRef] [PubMed]

17. Neubauer, H.; Kaiser, A.F.C.; Endres, H.G.; Krüger, J.C.; Engelhardt, A.; Lask, S.; Pepinghege, F.; Kusber, A.; Mügge, A. Tailored antiplatelet therapy can overcome clopidogrel and aspirin resistance-the BOchum CLopidogrel and Aspirin Plan (BOCLA-Plan) to improve antiplatelet therapy. BMC Med. 2011, 9, 3. [CrossRef] [PubMed]

18. Steiner, T.; Juvela, S.; Unterberg, A.; Jung, C.; Forsting, M.; Rinkel, G. European Stroke Organization guidelines for the management of intracranial aneurysms and subarachnoid haemorrhage. Cerebrovasc. Dis. 2013, 35, 93-112. [CrossRef]

19. Pan, C.J.; Tang, J.J.; Weng, Y.J.; Wang, J.; Huang, N. Preparation, characterization and anticoagulation of curcumin-eluting controlled biodegradable coating stents. J. Control. Release 2006, 116, 42-49. [CrossRef]

20. Kufner, S.; Joner, M.; Thannheimer, A.; Hoppmann, P.; Ibrahim, T.; Mayer, K.; Cassese, S.; Laugwitz, K.-L.; Schunkert, H.; Kastrati, A.; et al. Ten-year clinical outcomes from a trial of three limus-eluting stents with different polymer coatings in patients with coronary artery disease. Circulation 2019, 139, 325-333. [CrossRef]

21. Lopez-Donaire, M.L.; Santerre, J.P. Surface modifying oligomers used to functionalize polymeric surfaces: Consideration of blood contact applications. J. Appl. Polym. Sci. 2014, 131, 40328:1-40328:15. [CrossRef]

22. Muramatsu, T.; Onuma, Y.; Zhang, Y.-J.; Bourantas, C.V.; Kharlamov, A.; Diletti, R.; Farooq, V.; Gogas, B.D.; Garg, S.; García-García, H.M.; et al. Progress in treatment by percutaneous coronary intervention: The stent of the future. Rev. Esp. Cardiol. 2013, 66, 483-496. [CrossRef]

23. Kaplan, O.; Hierlemann, T.; Krajewski, S.; Kurz, J.; Nevoralová, M.; Houska, M.; Riedel, T.; Riedelová, Z.; Zárubová, J.; Wendel, H.P.; et al. Low-thrombogenic fibrin-heparin coating promotes in vitro endothelialization. J. Biomed. Mater. Res. A 2017, 105, 2995-3005. [CrossRef] 
24. Shuvalova, Y.A.; Shirokov, R.O.; Kaminnaya, V.I.; Samko, A.N.; Kaminnyi, A.I. Two-year follow-up of percutaneous coronary intervention using EucaTax or Cypher. Cardiovasc. Revasc. Med. 2013, 14, 284-288. [CrossRef] [PubMed]

25. Cutlip, D.E.; Garratt, K.N.; Novack, V.; Barakat, M.; Meraj, P.; Maillard, L.; Erglis, A.; Jauhar, R.; Popma, J.J.; Stoler, R.; et al. 9-month clinical and angiographic outcomes of the COBRA polyzene-f nanocoated coronary stent system. JACC Cardiovasc. Interv. 2017, 10, 160-167. [CrossRef] [PubMed]

26. Girdhar, G.; Li, J.; Kostousov, L.; Wainwright, J.; Chandler, W.L. In-vitro thrombogenicity assessment of flow diversion and aneurysm bridging devices. J. Thromb. Thrombolysis 2015, 40, 437-443. [CrossRef]

27. Martínez-Galdámez, M.; Lamin, S.M.; Lagios, K.G.; Liebig, T.; Ciceri, E.F.; Chapot, R.; Stockx, L.; Chavda, S.; Kabbasch, C.; Farago, G.; et al. Periprocedural outcomes and early safety with the use of the Pipeline Flex Embolization Device with Shield Technology for unruptured intracranial aneurysms: Preliminary results from a prospective clinical study. J. Neurointerv. Surg. 2017, 9, 772-776. [CrossRef]

28. Girdhar, G.; Ubl, S.; Jahanbekam, R.; Thinamany, S.; Belu, A.; Wainwright, J.; Wolf, M.F. Thrombogenicity assessment of Pipeline, Pipeline Shield, Derivo and P64 flow diverters in an in vitro pulsatile flow human blood loop model. eNeurologicalSci 2019, 14, 77-84. [CrossRef] [PubMed]

29. Martínez-Galdámez, M.; Gil, A.; Caniego, J.L.; Gonzalez, E.; Bárcena, E.; Perez, S.; Garcia-Bermejo, P.; Ortega-Gutierrez, S. Preliminary experience with the Pipeline Flex Embolization Device: Technical note. J. Neurointerv. Surg. 2015, 7, 748-751. [CrossRef]

30. Hanel, R.A.; Aguilar-Salinas, P.; Brasiliense, L.B.; Sauvageau, E. First US experience with Pipeline Flex with Shield Technology using aspirin as antiplatelet monotherapy. BMJ Case Rep. 2017, 2017. [CrossRef] [PubMed]

31. Lenz-Habijan, T.; Bhogal, P.; Peters, M.; Bufe, A.; Martinez Moreno, R.; Bannewitz, C.; Monstadt, H.; Henkes, H. Hydrophilic stent coating inhibits platelet adhesion on stent surfaces: Initial results in vitro. Cardiovasc. Intervent. Radiol. 2018, 41, 1779-1785. [CrossRef]

32. Colgan, F.; Aguilar Pérez, M.; Hellstern, V.; Reinhard, M.; Krämer, S.; Bäzner, H; Henkes, H. Vertebral Artery Aneurysm: Ruptured Dissecting Aneurysm, Implantation of Telescoping p48_HPC Flow Diverter Stents under Antiaggregation with ASA only: The Aneurysm Casebook: A Guide to Treatment Selection and Technique; Springer International Publishing: Cham, Switzerland, 2018; pp. 1-16.

33. Roos, E.; Maile, K.; Seidenfuß, M. Werkstoffkunde für Ingenieure. Grundlagen, Anwendung, Prüfung, 6., Ergänzte und bearbeitete Auflage; Springer Vieweg: Berlin/Heidelberg, Germany, 2017; ISBN 9783662495322.

34. Murphy, W.; Black, J.; Hastings, G. Handbook of Biomaterial Properties; Springer: New York, NY, USA, 2016; ISBN 978-1-4939-3303-7.

35. Williams, D.F. On the mechanisms of biocompatibility. Biomaterials 2008, 29, 2941-2953. [CrossRef]

36. Wintermantel, E.; Ha, S.-W. Medizintechnik. Life Science Engineering; Interdisziplinarität, Biokompatibilität, Technologien, Implantate, Diagnostik, Werkstoffe, Zertifizierung, Business, 5., überarb. und erw. Aufl.; Springer: Berlin/Heidelberg, Germany, 2009; ISBN 9783540939351.

37. Henkes, H.; Bhogal, P.; Aguilar Pérez, M.; Lenz-Habijan, T.; Bannewitz, C.; Peters, M.; Sengstock, C.; Ganslandt, O.; Lylyk, P.; Monstadt, H. Anti-thrombogenic coatings for devices in neurointerventional surgery: Case report and review of the literature. Interv. Neuroradiol. 2019, 25, 619-627. [CrossRef] [PubMed]

38. Kaps, M. Sonografie in der Neurologie; 3. Auflage; Georg Thieme Verlag: New York, NY, USA, 2017.

39. Horbett, T.A. The role of adsorbed proteins in animal cell adhesion. Colloids Surf. B Biointerfaces 1994, 2, 225-240. [CrossRef]

40. Xu, L.-C.; Bauer, J.W.; Siedlecki, C.A. Proteins, platelets, and blood coagulation at biomaterial interfaces. Colloids Surf. B Biointerfaces 2014, 124, 49-68. [CrossRef] [PubMed]

41. Maxisch, M.; Ebbert, C.; Torun, B.; Fink, N.; de los Arcos, T.; Lackmann, J.; Maier, H.J.; Grundmeier, G. PM-IRRAS studies of the adsorption and stability of organophosphonate monolayers on passivated NiTi surfaces. Appl. Surf. Sci. 2011, 257, 2011-2018. [CrossRef]

42. de Scheerder, I.; Verbeken, E.; van Humbeeck, J. Metallic surface modification. Semin. Interv. Cardiol. 1998, 3, 139-144. [PubMed]

43. Sojitra, P.; Engineer, C.; Kothwala, D.; Raval, A.; Kotadia, H.; Mehta, G. Investigation of material removal, surface roughnessand corrosion behaviour: Surface roughnessand corrosion behaviour. Trends Biomater. Artif. Organs 2010, $23,115-121$.

44. Bracco, G.; Holst, B. Surface Science Techniques; Springer: Berlin/Heidelberg, Germany, 2013; ISBN 9783642342431.

45. Faucheux, N.; Schweiss, R.; Lützow, K.; Werner, C.; Groth, T. Self-assembled monolayers with different terminating groups as model substrates for cell adhesion studies. Biomaterials 2004, 25, 2721-2730. [CrossRef]

46. Harnett, E.M.; Alderman, J.; Wood, T. The surface energy of various biomaterials coated with adhesion molecules used in cell culture. Colloids Surf. B Biointerfaces 2007, 55, 90-97. [CrossRef]

47. Wan, G.J.; Huang, N.; Yang, P.; Fu, R.K.Y.; Ho, J.P.Y.; Xie, X.; Zhou, H.F.; Chu, P.K. Platelet activation behavior on nitrogen plasma-implanted silicon. Mater. Sci. Eng. C 2007, 27, 928-932. [CrossRef]

48. Yang, P.; Huang, N.; Leng, Y.X.; Yao, Z.Q.; Zhou, H.F.; Maitz, M.; Leng, Y.; Chu, P.K. Wettability and biocompatibility of nitrogen-doped hydrogenated amorphous carbon films: Effect of nitrogen. Nucl. Instrum. Methods Phys. Res. Sect. B Beam Interact. Mater. At. 2006, 242, 22-25. [CrossRef]

49. Tzoneva, R.; Groth, T.; Altankov, G.; Paul, D. Remodeling of fibrinogen by endothelial cells in dependence on fibronectin matrix assembly. Effect of substratum wettability. J. Mater. Sci. Mater. Med. 2002, 13, 1235-1244. [CrossRef] [PubMed]

50. Arima, Y.; Iwata, H. Effect of wettability and surface functional groups on protein adsorption and cell adhesion using well-defined mixed self-assembled monolayers. Biomaterials 2007, 28, 3074-3082. [CrossRef] [PubMed] 
51. Bhogal, P.; Lenz-Habijan, T.; Bannewitz, C.; Hannes, R.; Monstadt, H.; Simgen, A.; Mühl-Benninghaus, R.; Reith, W.; Henkes, H. The pCONUS HPC: 30-day and 180-day in vivo biocompatibility results. Cardiovasc. Intervent. Radiol. 2019, 42, $1008-1015$. [CrossRef]

52. Lenz-Habijan, T.; Bhogal, P.; Bannewitz, C.; Hannes, R.; Monstadt, H.; Simgen, A.; Mühl-Benninghaus, R.; Reith, W.; Henkes, H. Prospective study to assess the tissue response to HPC-coated p48 flow diverter stents compared to uncoated devices in the rabbit carotid artery model. Eur. Radiol. Exp. 2019, 3, 47. [CrossRef] [PubMed]

53. Beythien, C.; Terres, W.; Hamm, C.W. In vitro model to test the thrombogenicity of coronary stents. Thromb. Res. 1994, 75, 581-590. [CrossRef]

54. Miyazaki, Y.; Nomura, S.; Miyake, T.; Kagawa, H.; Kitada, C.; Taniguchi, H.; Komiyama, Y.; Fujimura, Y.; Ikeda, Y.; Fukuhara, S. High shear stress can initiate both platelet aggregation and shedding of procoagulant containing microparticles. Blood 1996, 88, 3456-3464. [CrossRef] [PubMed]

55. van Beusekom, H.M.M.; van der Giessen, W.J.; van Suylen, R.J.; Bos, E.; Bosman, F.; Serruys, P.W. Histology after stenting of human saphenous vein bypass grafts: Observations from surgically excised grafts 3 to 320 days after stent implantation. J. Am. Coll. Cardiol. 1993, 21, 45-54. [CrossRef] 